\title{
A Test of the Catering Theory of Dividends: The Case of the Japanese Electric Appliances Industry
}

\author{
Chikashi Tsuji \\ Graduate School of Systems and Information Engineering \\ University of Tsukuba \\ E-mail: mail_sec_low@minos.ocn.ne.jp
}

\begin{abstract}
We test the catering theory of dividends using data from firms in the Japanese electrical appliances industry. Our empirical investigations reveal that, in the Japanese electrical appliances industry, corporate managers do not consider catering behavior in either their dividend initiation decisions or their continuation decisions. This result is particularly important because it is different from existing evidence for the US. We also find that one of the most important determinants of dividend initiations among Japanese electrical appliances industry firms is the value-weighted dividend yield in the industry. Namely, we find that after the value-weighted dividend yield declines, Japanese firms in the industry tend to initiate dividend payments.
\end{abstract}

Keywords: Catering theory of dividends, Dividend policy, Imperfect market, Inefficient market. 


\section{Introduction}

Miller and Modigliani (MM) (1961) proved that dividend policy is irrelevant to share value in perfect and efficient capital markets. After the proof was published, many researchers criticized it using various approaches (Note 1).

Recently, a new theory called the "catering theory of dividends" was developed by Baker and Wurgler (BW) (2004a). Relaxing the assumption of perfect markets and efficient markets (Note 2) undertaken in MM (1961) and considering psychological and institutional reasons, BW (2004a) suggested the following by constructing a simple theoretical model. First, some investors have an uninformed and perhaps time-varying demand for dividend-paying stocks. Second, arbitrage fails to prevent this demand from driving apart the prices of dividend payers and nonpayers. Third, managers rationally cater to investor demand-they pay dividends when investors put higher prices on payers, and they do not pay when investors prefer nonpayers.

As far as we know, this new theory has not been tested for Japan; thus, testing catering theory using Japanese data is an objective of this paper. More precisely, we test the catering theory of dividends in the Japanese electrical appliances industry, one of the most important industries in Japan.

The results derived in this paper are as follows. First, our investigations reveal that the dividend initiation decisions of Japanese electrical appliances industry firms have no predictive power for the relative future returns of payers over nonpayers. While BW (2004a) documented that US firms' dividend decisions for both initiations and continuations have strong predictive power for relative negative future returns, our results are different from them.

Second, regarding the determinants of the dividend initiations, the first difference between the US and Japan is that the value-weighted dividend yield is a strong determinant of one-year-ahead dividend initiations in the Japanese electrical appliances industry firms. Most importantly, the dividend premium is not a determinant of the dividend initiations of the Japanese electrical appliances industry firms. This means that these firms do not behave as predicted by catering theory.

Moreover, regarding the dividend continuation decisions, in contrast to the US case, the dividend premium has again no relation with the dividend continuation decisions in the case of the Japanese electrical appliances industry firms. Hence, again, our empirical evidence suggests that these firms do not behave as predicted by catering theory.

The rest of the paper is organized as follows. Section 2 summarizes BW's (2004a) catering theory of dividends, Section 3 explains the data, Section 4 describes the empirical results, Section 5 performs alternative tests, Section 6 implements the robustness checks, Section 7 interprets the results, and Section 8 concludes the paper.

\section{Catering Theory}

The catering theory of dividends, developed by BW (2004a), suggests that real financial 
markets are imperfect and inefficient, and corporations decide their dividend initiation and continuation decisions by catering to investors' demands for dividends.

Typically, in BW (2004a), investors' demands for dividends can be captured by the difference between payers' market-to-book ratios (M/Bs) and nonpayers' market-to-book ratios (M/Bs), which corporate managers can observe through financial markets. Hence, catering theory predicts that if the difference between payers' $\mathrm{M} / \mathrm{Bs}$ and nonpayers' $\mathrm{M} / \mathrm{Bs}$ increases, corporate managers decide on dividend initiations or dividend continuations by catering to investors' dividend demands.

\section{Data}

Our dividend payment measures follow BW (2004a). All data in this study are from QUICK Corp. Our full sample period is from 1986 to 2006, and our focus in this study is on the firms in the Japanese electrical appliances industry. The industry is important because the largest number of firms of the industry is included in the universe of the NIKKEI 500 Index as at the end of December 2009. In accordance with BW (2004a), we count a firm as a payer if it has positive dividends per share by the ex date, or else it is a nonpayer. To aggregate this firm-level data into useful time series data, we use two aggregate identities following BW (2004a):

$$
\text { Payers }_{t}=\text { New Payers }+ \text { Old Payers }+ \text { List Payers },
$$

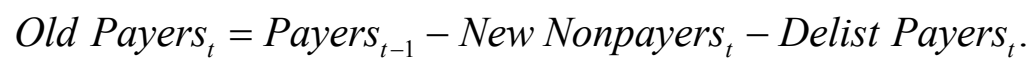

The first identity defines the number of payers and the second describes the evolution. Payers is the total number of payers; New Payers is the number of initiators among last year's nonpayers; Old Payers is the number of payers that also paid last year; List Payers is the number of payers this year that were not in the sample last year; New Nonpayers is the number of nonpayers among last year's payers; and Delist Payers is the number of last year's payers not in the sample this year. Note that lists and delists refer to companies added to and removed from the Tokyo Stock Exchange First Section, respectively.

We then define three variables to capture the dividend payment dynamics as in BW (2004a):

$$
\begin{aligned}
& \text { Initiate }_{t}=\frac{\text { New Payers }_{t}}{\text { Nonpayers }_{t-1}-\text { Delist Nonpayers }_{t}}, \\
& \text { Continue }_{t}=\frac{\text { Old Payers }_{t}}{\text { Payers }_{t-1}-\text { Delist Payers }_{t}}, \\
& \text { Listpay }_{t}=\frac{\text { List Payers }_{t}}{\text { List Payers }_{t}+\text { List Nonpayers }_{t}} .
\end{aligned}
$$


In words, the rate of initiation Initiate is the fraction of surviving nonpayers that become new payers. The rate at which firms continue paying Continue is the fraction of surviving payers that continue paying. The rate at which new lists in the sample pay Listpay is payers as a percentage of new lists at time $t$. These variables capture the decision whether to pay dividends, not how much to pay.

Table 1 lists the aggregate totals and the dividend payment variables for the Japanese electrical appliances industry. The initiation rate starts out low in 1987, then increases in the beginning of the 1990s, and then falls. After that, it rebounds in the late 1990s, decreases again in 2002, and increases again around the end of the sample. The rate at which firms continue paying varies less, as expected. Note that the rate at which lists pay is always high, in contrast with the case of BW (2004a) where Listpay varies significantly.

Next are the stock market dividend premium variables. Namely, we relate dividend payment choices to several stock-market-based measures of the uninformed demand for dividend-paying shares (i.e., the dividend premium) as BW (2004a) suggested.

Conceptually, it is important to measure the difference between the market prices of firms with the same investment policy and different dividend policies, because in the frictionless and efficient markets of MM (1961), this price difference should be zero. However, with limits to arbitrage, BW (1961) suggested that the uninformed demand for dividend-paying shares causes a price difference, which may vary over time.

Our first stock market dividend premium variable is the dividend premium of BW (2004a), denoted as $P^{D-N D}$. It is the difference in the logs of the average market-to-book ratios of payers and nonpayers. We define market-to-book following Fama and French $(1993 ; 1996)$. The market-to-book ratio is book assets minus book equity plus market equity, all divided by book assets.

More precisely, we take equal- and (book) value-weighted averages of the market-to-book ratios separately for payers and nonpayers in each year. Then we construct the final dividend premium series as the difference of the logs of these averages. These series are listed in Table 2 and the value-weighted series of payers' and nonpayers' $\mathrm{M} / \mathrm{B}$ ratios and the value-weighted dividend premium are plotted in panels A and B of Figure 1, respectively. The figure shows that the dividend premium increases after 1997. This is because some of the larger companies in the Japanese electrical appliances industry are valued highly in the Japanese stock market.

Our second measure of the relative stock market valuation of dividend payers is the difference between the future (book) value-weighted returns of payers and nonpayers. According to the model of BW (2004a), managers rationally initiate dividends to exploit an apparent market mispricing. BW (2004a) suggested that if this is literally the case, a high rate of initiations should forecast low returns on payers relative to nonpayers as the relative overpricing of payers reverses. 
Table 1. Measures of Dividend Payment

\begin{tabular}{cccccccccccc}
\hline & \multicolumn{4}{c}{ Payers } & \multicolumn{4}{c}{ Nonpayers } & \multicolumn{3}{c}{ Payment Rates (\%) } \\
\cline { 2 - 11 } Year & Total & New & Old & List & Total & New & Old & List & Initiate & Continue & Listpay \\
\hline 1987 & 91 & 0 & 86 & 5 & 12 & 5 & 7 & 0 & 0.00 & 95.56 & 100.00 \\
1988 & 94 & 2 & 90 & 2 & 11 & 1 & 10 & 0 & 16.67 & 98.90 & 100.00 \\
1989 & 98 & 3 & 93 & 2 & 9 & 1 & 8 & 0 & 27.27 & 98.94 & 100.00 \\
1990 & 104 & 4 & 98 & 2 & 5 & 0 & 5 & 0 & 44.44 & 100.00 & 100.00 \\
1991 & 108 & 1 & 103 & 4 & 5 & 1 & 4 & 0 & 20.00 & 99.04 & 100.00 \\
1992 & 108 & 0 & 103 & 5 & 10 & 5 & 5 & 0 & 0.00 & 95.37 & 100.00 \\
1993 & 99 & 0 & 98 & 1 & 20 & 10 & 10 & 0 & 0.00 & 90.74 & 100.00 \\
1994 & 89 & 0 & 86 & 3 & 30 & 8 & 21 & 1 & 0.00 & 90.53 & 75.00 \\
1995 & 93 & 2 & 89 & 2 & 28 & 0 & 28 & 0 & 6.67 & 100.00 & 100.00 \\
1996 & 97 & 7 & 89 & 1 & 26 & 4 & 21 & 1 & 25.00 & 95.70 & 50.00 \\
1997 & 106 & 4 & 96 & 6 & 23 & 1 & 22 & 0 & 15.38 & 98.97 & 100.00 \\
1998 & 115 & 6 & 104 & 5 & 19 & 2 & 17 & 0 & 26.09 & 98.11 & 100.00 \\
1999 & 110 & 2 & 104 & 4 & 28 & 11 & 17 & 0 & 10.53 & 90.43 & 100.00 \\
2000 & 118 & 6 & 103 & 9 & 26 & 5 & 21 & 0 & 22.22 & 95.37 & 100.00 \\
2001 & 133 & 8 & 112 & 13 & 20 & 3 & 17 & 0 & 33.33 & 96.55 & 100.00 \\
2002 & 112 & 0 & 110 & 2 & 41 & 22 & 19 & 0 & 0.00 & 83.33 & 100.00 \\
2003 & 114 & 10 & 100 & 4 & 36 & 8 & 28 & 0 & 26.32 & 92.59 & 100.00 \\
2004 & 126 & 15 & 110 & 1 & 21 & 1 & 19 & 1 & 44.12 & 99.10 & 85.71 \\
2005 & 146 & 8 & 129 & 9 & 16 & 1 & 13 & 2 & 38.10 & 99.23 & 81.82 \\
2006 & 146 & 3 & 140 & 3 & 19 & 6 & 13 & 0 & 18.75 & 95.89 & 100.00 \\
\hline \hline
\end{tabular}

Notes: A firm is defined as a dividend payer at time $t$ if it has positive dividends per share by the ex date. A firm is defined as a new dividend payer at time $t$ if it has positive dividends per share by the ex date at time $t$ and zero dividends per share by the ex date at time $t-1$. A firm is defined as an old payer at time $t$ if it has positive dividends per share by the ex date at time $t$ and positive dividends per share by the ex date at time $t-1$. A firm is defined as a new list payer if it has positive dividends per share by the ex date at time $t$ and is not in the sample at time $t-1$. A firm is defined as a nonpayer at time $t$ if it does not have positive dividends per share by the ex date. New nonpayers are firms who were payers at time $t-1$ but not at $t$. Old nonpayers are firms who were nonpayers in both $t-1$ and $t$. New list nonpayers are nonpayers at $t$ who were not in the sample at $t-1$. The initiation rate Initiate expresses payers as a percentage of surviving nonpayers from $t-1$. The rate at which firms continue paying dividends Continue expresses payers as a percentage of surviving payers from $t-$ 1. The rate at which lists pay Listpay expresses payers as a percentage of new lists at $t$.

Table 2. The Dividend Premium

\begin{tabular}{ccccccc}
\hline \hline & \multicolumn{3}{c}{ Payers } & \multicolumn{2}{c}{ Nonpayers } & \multicolumn{2}{c}{ Dividend Premium $\left(P^{D-N D}\right)$} \\
\cline { 2 - 6 } Year & EWM/B & VWM/B & EWM/B & VWM/B & EW & VW \\
\hline 1986 & 1.95 & 1.66 & 1.52 & 1.51 & 25.00 & 9.83 \\
1987 & 1.81 & 1.64 & 1.50 & 1.42 & 18.45 & 14.33 \\
1988 & 2.21 & 2.03 & 1.90 & 1.78 & 15.08 & 13.29 \\
1989 & 2.11 & 1.98 & 2.20 & 2.13 & -4.23 & -7.03 \\
1990 & 2.35 & 2.01 & 3.11 & 2.78 & -28.08 & -32.25 \\
1991 & 1.91 & 1.64 & 1.51 & 1.38 & 23.37 & 17.41 \\
1992 & 1.44 & 1.29 & 1.68 & 1.62 & -15.32 & -22.18 \\
1993 & 1.44 & 1.29 & 1.45 & 1.26 & -1.13 & 2.43 \\
1994 & 1.75 & 1.47 & 1.55 & 1.44 & 11.94 & 2.63 \\
1995 & 1.44 & 1.33 & 1.44 & 1.30 & -0.30 & 2.49 \\
1996 & 1.59 & 1.48 & 1.64 & 1.56 & -2.70 & -5.46 \\
1997 & 1.50 & 1.49 & 1.38 & 1.28 & 7.77 & 15.38 \\
1998 & 1.37 & 1.47 & 1.13 & 1.20 & 18.59 & 20.21 \\
1999 & 1.48 & 1.57 & 1.11 & 1.15 & 28.81 & 30.70 \\
2000 & 2.08 & 2.48 & 1.70 & 1.30 & 20.27 & 64.33 \\
2001 & 1.52 & 1.76 & 1.65 & 1.14 & -7.91 & 43.08 \\
2002 & 1.49 & 1.70 & 1.66 & 1.24 & -11.21 & 31.44 \\
2003 & 1.21 & 1.34 & 1.81 & 1.00 & -39.76 & 28.73 \\
2004 & 1.54 & 1.56 & 1.70 & 1.34 & -10.02 & 15.23 \\
2005 & 1.53 & 1.49 & 1.39 & 1.32 & 9.57 & 11.96 \\
2006 & 1.89 & 1.85 & 1.62 & 1.42 & 15.11 & 26.44 \\
\hline \hline
\end{tabular}

Notes: A firm is defined as a dividend payer at time $t$ if it has positive dividends per share by the ex date. The market-to-book ratio is the ratio of the market value of the firm to its book value. The market-to-book ratio reported is an equal-weighed (EW) or value-weighted (VW) average, by book value across dividend payers and nonpayers. These ratios are calculated for the entire sample and for new lists. A firm is defined as a new list if it is not in the sample at time $t-1$. The dividend premium $P^{D-N D}$ is the difference between the logs of the dividend payers' and nonpayers' average market-to-book ratios. 
Table 3 reports the correlations among dividend premiums $P^{D-N D}$ and future returns. The excess return on payers over nonpayers in year $t+1$ is denoted as $r_{D t+1}-r_{N D t+1}$ and the cumulative excess return on payers over nonpayers from years $t+1$ through $t+3$ is denoted as $R_{D t+3}-R_{N D t+3}$. The table indicates that both equally weighted and value-weighted dividend premiums are negatively correlated with the cumulative excess return of payers over nonpayers from years $t+1$ through $t+3$. These negative correlations imply that, after dividend payers are overvalued, their market values mean-revert and, as a result, future three-year cumulative excess returns on payers over nonpayers drop. Hence, the implications of these negative correlations are the possibility of market inefficiency in the Japanese stock market differently from the setting of market efficiency in MM (1961).

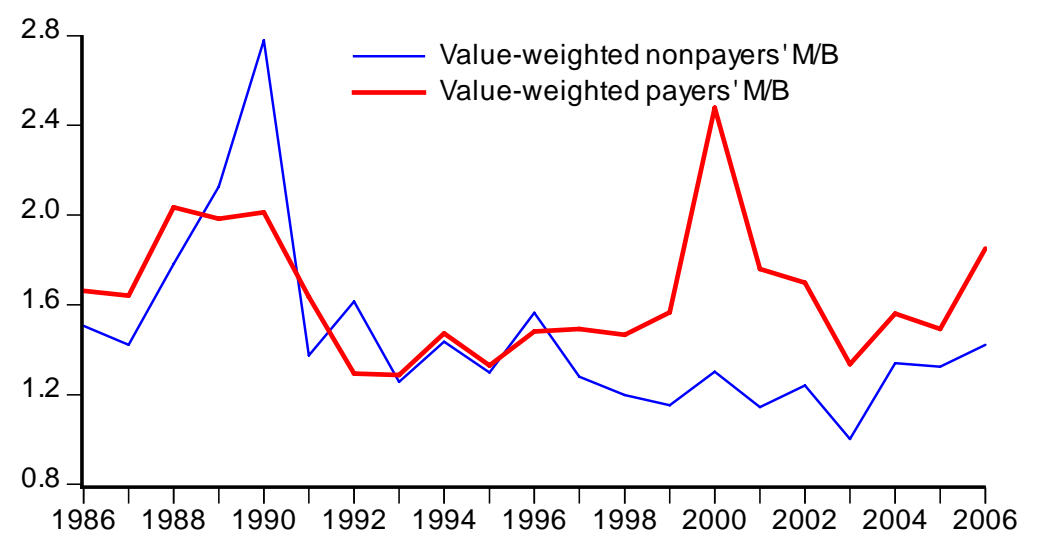

Panel A. Average M/B ratios of payers and nonpayers

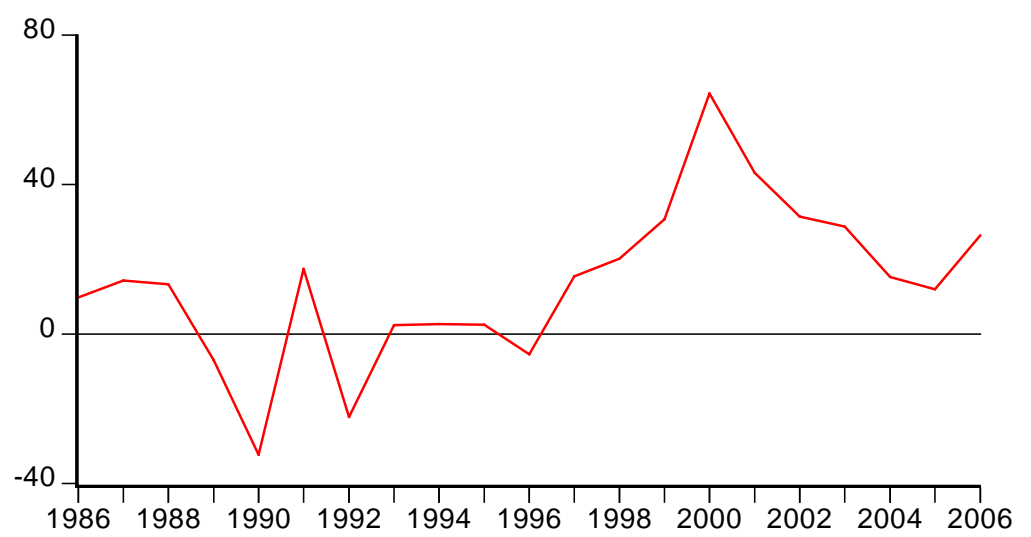

Panel B. Value-weighted dividend premium (\%)

Figure 1. Valuation of dividend payers and nonpayers and the dividend premium.

The (book) value-weighted average market-to-book ratio for dividend payers and nonpayers and the dividend premium (the $\log$ difference in average market-to-book ratios) is displayed. A firm is defined as a dividend payer at time $t$ if it has positive dividends per share by the ex date. The market-to-book ratio is the ratio of the market value of the firm to its book value. The average market-to-book ratios are constructed by value-weighting (by book value) across dividend payers and nonpayers and are plotted in Panel A. Panel B plots the value weighted dividend premium of the Japanese electric appliances industry. 
Table 3. Correlation Coefficients among Dividend Premium and Future Returns

\begin{tabular}{lcccc}
\hline & \multicolumn{2}{c}{ Dividend Premium } & \multicolumn{2}{c}{ Future Returns } \\
\cline { 2 - 5 } & $\mathrm{VW}$ & $\mathrm{EW}$ & $r_{D t+1}-r_{N D t+1}$ & $R_{D t+3}-R_{N D t+3}$ \\
\hline $\mathrm{VW} P_{t}^{D-N D}$ & 1.00 & & & \\
$\mathrm{EW} P_{t}^{D-N D}$ & 0.35 & 1.00 & & \\
$r_{D t+1}-r_{N D t+1}$ & -0.11 & 0.36 & 1.00 & 1.00 \\
$R_{D t+3}-R_{N D t+3}$ & -0.34 & -0.05 & 0.41 & \\
\hline \hline
\end{tabular}

Notes: The table shows the correlations among the variables. The dividend premium $P^{D-N D}$ is the difference between the logs of the EW and VW market-to-book ratios for dividend payers and nonpayers. Future relative returns $r_{D t+1}-r_{N D t+1}$ is the difference in returns for (book) value-weighted indexes of dividend payers and nonpayers in year $t+1$. Future relative returns $R_{D t+3}-R_{N D t+3}$ is the cumulative difference in future returns from year $t+1$ through $t+3$. Correlation coefficients displayed are those among raw variables.

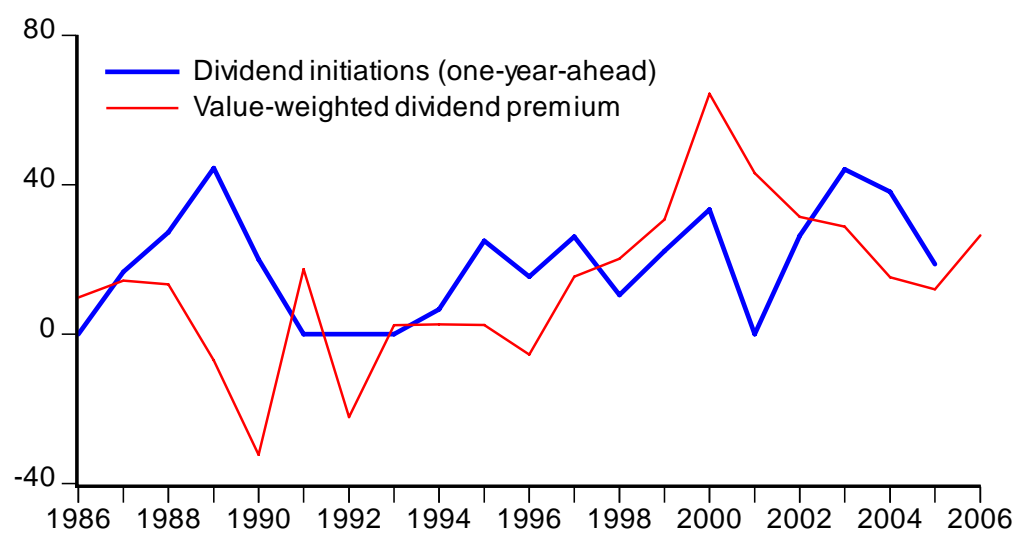

Figure 2. The dividend premium and the rate of dividend initiation.

The log difference in the market-to-book ratio of dividend payers and nonpayers and one-year-ahead rate of dividend initiations are displayed. A firm is defined as a dividend payer at time $t$ if it has positive dividends per share by the ex date. The initiation rate Initiate in $t+1$ is defined as the percentage rate of new dividend payers at time $t+1$ among surviving nonpayers from $t$.

Table 4. Dividend Payment and Demand for Dividends: Basic Relationships

\begin{tabular}{|c|c|c|c|c|}
\hline \multirow{2}{*}{$\mathrm{VW} P^{D-N D}{ }_{t-1}$} & \multicolumn{2}{|c|}{ Panel A: Initiate } & \multicolumn{2}{|c|}{ Panel B: Continue ${ }_{t}$} \\
\hline & $\begin{array}{c}2.80 \\
{[0.34]}\end{array}$ & & $\begin{array}{c}-1.13 \\
{[0.24]}\end{array}$ & \\
\hline $\mathrm{EW} P^{D-N D}{ }_{t-1}$ & & $\begin{array}{c}-4.61 \\
{[0.17]}\end{array}$ & & $\begin{array}{l}0.001 \\
{[1.00]}\end{array}$ \\
\hline$N$ & 20 & 20 & 20 & 20 \\
\hline Adj. $R^{2}$ & -0.02 & 0.05 & 0.01 & -0.06 \\
\hline
\end{tabular}

Notes: Regressions of dividend initiation and continuation rates on measures of the dividend premium. For example, the initiation rate is modeled in Panel A as: Initiate $_{t}=\mu+\xi P^{D-N D}{ }_{t-1}+\eta_{t}$.

The initiation rate Initiate expresses payers as a percentage of surviving nonpayers from $t-1$. The continuation rate Continue expresses payers as a percentage of surviving payers from $t-1$. The dividend premium $P^{D-N D}$ is the difference between the logs of the EW and VW market-to-book ratios for dividend payers and nonpayers. The independent variables are standardized to have unit variance. $p$-values in [ ] are robust to heteroskedasticity and serial correlation because the method of Newey and West (1987) is used. $N$ is the number of sample and $A d j . R^{2}$ is the adjusted $R$-squared value. 
Table 5. Dividend Payment and Demand for Dividends: Predicting Returns

\begin{tabular}{|c|c|c|c|c|c|c|c|}
\hline & \multirow[b]{2}{*}{$N$} & \multicolumn{3}{|c|}{ Initiate $_{t}$} & \multicolumn{3}{|c|}{ Continue $_{t}$} \\
\hline & & Coefficients & $p$-value & Adj.R $R^{2}$ & Coefficients & $p$-value & Adj.R $R^{2}$ \\
\hline \multicolumn{8}{|c|}{ Panel A: Relative Returns } \\
\hline$r_{D t+1}-r_{N D t+1}$ & 20 & 2.82 & 0.27 & -0.04 & 0.95 & 0.83 & -0.05 \\
\hline$r_{D t+2}-r_{N D t+2}$ & 20 & 4.15 & 0.30 & 0.04 & $6.66 * *$ & 0.02 & 0.05 \\
\hline$r_{D t+3}-r_{N D t+3}$ & 20 & 0.31 & 0.95 & -0.06 & 2.36 & 0.44 & -0.04 \\
\hline$R_{D t+3}-R_{N D t+3}$ & 20 & 3.33 & 0.36 & 0.01 & $3.66^{* *}$ & 0.03 & 0.02 \\
\hline \multicolumn{8}{|c|}{ Panel B: Payer Returns } \\
\hline$r_{D t+1}$ & 20 & -3.93 & 0.54 & -0.04 & 0.01 & 1.00 & -0.06 \\
\hline$r_{D t+2}$ & 20 & -7.70 & 0.31 & 0.02 & -6.77 & 0.39 & 0.00 \\
\hline$r_{D t+3}$ & 20 & -0.12 & 0.98 & -0.06 & -0.75 & 0.88 & -0.05 \\
\hline$R_{D t+3}$ & 20 & -3.59 & 0.32 & 0.00 & -1.27 & 0.63 & -0.05 \\
\hline \multicolumn{8}{|c|}{ Panel C: Nonpayer Returns } \\
\hline$r_{N D t+1}$ & 20 & -6.75 & 0.38 & -0.03 & -0.94 & 0.90 & -0.06 \\
\hline$r_{N D t+2}$ & 20 & $-11.84 * *$ & 0.04 & 0.12 & $-13.43 * *$ & 0.05 & 0.17 \\
\hline$r_{N D t+3}$ & 20 & -0.43 & 0.96 & -0.06 & -3.11 & 0.48 & -0.05 \\
\hline$R_{N D t+3}$ & 20 & -6.92 & 0.21 & 0.04 & $-4.94^{*}$ & 0.09 & -0.01 \\
\hline
\end{tabular}

Notes: Univariate regressions of future excess returns of dividend payers over nonpayers on the initiation rate and the continuation rate. The dependent variables in Panel A are the differences in returns between dividend payers $r_{D}$ and nonpayers $r_{N D}$. The dependent variables in Panel B are returns of dividend payers $r_{D}$. The dependent variables in Panel C are the returns of nonpayers $r_{N D}$. $R_{t+k}$ denotes cumulative returns from $t+1$ through $t+k$. The initiation rate Initiate expresses new payers as a percentage of surviving nonpayers from $t-1$. The continuation rate Continue expresses continuing payers as a percentage of surviving payers from $t-1$. The independent variables are standardized to have unit variance. $p$-values are robust to heteroskedasticity and serial correlation because the method of Newey and West (1987) is used. $N$ is the number of sample and $A d j . R^{2}$ is the adjusted $R$-squared value.* denotes statistical significance at the $10 \%$ level and $* *$ denotes statistical significance at the $5 \%$ level.

\section{Empirical Tests}

Here we check the relation between dividend payments and the stock market measures of dividend demand. Figure 2 shows a positive relation between the dividend premium and the raw rate of dividend initiation in the following year.

To examine this relationship formally, in Table 4 we show the results of regressing dividend payment measures on the lagged demand for dividends measures. More precisely, we estimate:

$$
\begin{aligned}
& \text { Initiate }_{t}=\mu+\xi P_{t-1}^{D-N D}+\eta_{t}, \\
& \text { Continue }_{t}=\mu+\xi P_{t-1}^{D-N D}+\eta_{t},
\end{aligned}
$$

where Initiate is the rate of initiation, Continue is the rate of continuation, and $P^{D-N D}$ is the market dividend premium (value-weighted or equally weighted). In the tables, all independent variables are standardized to have unit variance and all standard errors are robust to heteroskedasticity and serial correlation using the procedure of Newey and West (1987).

Panel A of Table 4 reports that neither an increase in the value-weighted market dividend premium nor an increase in the equally weighted market dividend premium is associated with an increase in the dividend initiation rate in the following year. Similarly, neither an increase in the value-weighted market dividend premium nor an increase in the equally weighted market dividend premium is associated with an increase in the dividend continuation rate in the following year. To sum up, in contrast with the US case in BW (2004a), judging by the dividend premium measure, the dividend policies of the Japanese electrical appliances 
industry firms do not cater to investor dividend demand.

Next, Table 5 shows the relationship between dividend policy and the second dividend demand proxy: future excess returns of payers over nonpayers. In panel A, the dependent variables are the differences between the returns on the value-weighted indexes of payers and nonpayers. Panels B and C look at the returns on payers and nonpayers, respectively, to examine whether the results for relative returns are indeed a result of the difference in returns, which the theory emphasizes, or payer or nonpayer returns alone. Each panel examines one-, two-, and three-year-ahead returns, and cumulative three-year returns. The table reports ordinary least-squares coefficients.

BW (2004a) documented that US firms' dividend decisions both for initiations and continuations have strong predictive power for relative negative future returns. However, in contrast with the results of BW (2004a), panel A of Table 5 indicate that the dividend initiation and continuation decisions of the Japanese electrical appliances industry firms predict the weakly positive relative future returns although the coefficients are not always statistically significant. This is because, after dividend initiations and continuations, the returns of payers decrease; however, nonpayers continuously record larger negative returns and, as a result, the future excess returns of payers over nonpayers become positive.

\section{Alternative Tests}

BW (2004a) suggested that the catering explanation for US dividend policy is robust and that dividend payments are, to some extent, a rational managerial response to investor demand pressures that cause a stock market mispricing. However, in the Japanese electrical appliances industry, this is not the case.

Therefore, this section provides an alternative explanation using the following kinds of model:

$$
\begin{gathered}
\text { Initiate }_{t}=\alpha+\vartheta_{1} V W P_{t-1}^{D-N D}+\vartheta_{2} \text { VWNonpayerM } / B_{t-1} \\
+\vartheta_{3} \text { VWD } / P_{t-1}+\vartheta_{4} \text { Tax }_{t-1}+\vartheta_{5} \text { Year }_{t-1}+\tau_{t}, \\
\text { Continue }_{t}=\alpha+\vartheta_{1} V W P_{t-1}^{D-N D}+\vartheta_{2} \text { VWPayerM } / B_{t-1} \\
+\vartheta_{3} V W D / P_{t-1}+\vartheta_{4} \text { Tax }_{t-1}+\vartheta_{5} \text { Year }_{t-1}+\tau_{t},
\end{gathered}
$$

where $V W P^{D-N D}$ is the book value-weighted dividend premium, $V W N$ onpayer $M / B$ is the book value-weighted nonpayers' market-to-book ratio, $V W$ PayerM/B denotes the book value-weighted payers' market-to-book ratio, $V W D / P$ denotes the book value-weighted dividend-yield, Year is an annual time trend variable, and Tax denotes the ratio of after-tax income from dividends relative to after-tax income from capital gains. Hence, the variable Tax measures the favorability of dividends in comparison with capital gains from a viewpoint of the Japanese tax system.

Table 6 displays the results of various regressions, which are in contrast with those of BW (2004a). The results suggest that, for the Japanese electrical appliances industry firms (1), the 
value-weighted dividend yield is a strong determinant of one-year-ahead dividend initiations, and (2) in contrast to the US case, the dividend premium is not related to the dividend initiations. These two results are seen in panel A of Table 6. Moreover, panel B of Table 6 indicates that, in contrast to the US case, the dividend premium is also not related to the dividend continuations in the Japanese electrical appliances industry.

\section{Robustness Checks}

To test that the above results are robust, this section conducts robustness checks using the following kinds of model:

$$
\begin{aligned}
& \text { Initiate }_{t}=\alpha+\vartheta_{1} M V W P_{t-1}^{D-N D}+\vartheta_{2} M V W N \text { onpayerM } / B_{t-1} \\
& +\vartheta_{3} M V W D / P_{t-1}+\vartheta_{4} \text { Tax }_{t-1}+\vartheta_{5} \text { Year }_{t-1}+\tau_{t}, \\
& \text { Continue }_{t}=\alpha+\vartheta_{1} M V W P_{t-1}^{D-N D}+\vartheta_{2} M V W P a y e r M / B_{t-1} \\
& +\vartheta_{3} M V W D / P_{t-1}+\vartheta_{4} \text { Tax }_{t-1}+\vartheta_{5} \text { Year }_{t-1}+\tau_{t},
\end{aligned}
$$

where $M V W P^{D-N D}$ is the market value-weighted dividend premium, $M V W N o n p a y e r M / B$ is the market value-weighted nonpayers' market-to-book ratio, $M V W P a y e r M / B$ denotes the market value-weighted payers' market-to-book ratio, $M V W D / P$ denotes the market value-weighted dividend-yield, and Year and Tax are the same as in the previous section.

Table 7 shows the results of various regressions similar to those in Table 6 . The results in Table 7 again indicate (1) the value-weighted dividend yield is a strong determinant of one-year-ahead dividend initiations, and (2) the dividend premium is neither related to the dividend initiations nor continuations in the Japanese electrical appliances industry. Hence, our empirical results demonstrated in this paper are robust for the Japanese electrical appliances industry.

\section{Interpretations}

How can we interpret our empirical results? First, in the context of catering theory, corporations in the Japanese electrical appliances industry decide their dividend initiation and continuation without catering for the investors' demands for dividends.

Based on the results of the statistical significance of the value-weighted dividend yields with negative sign for the dividend initiations, corporations in the Japanese electrical appliances industry decide their dividend initiation by considering their own industry's valuation in the markets. Because the level of dividends is generally not volatile in Japan, changes in the dividend yields mainly come from changes in the stock price. According to our results, the Japanese electrical appliances industry firms initiate a dividend when the value of the industry in the stock market is high. Hence, the nonpayers in the industry take into account their industry's total value in the stock market in their decision regarding dividend initiations. The basis of this type of corporate behavior might be the recognition of high industry values as the time to start fulfilling the firm's responsibility to their shareholders. However, this is difficult to confirm without collecting information using questionnaires from Chief Financial 
Officers, for example.

Table 6. Dividend Payment and the Dividend Premium: Tests with Other Book Value-Weighted Variables

\begin{tabular}{|c|c|c|c|c|c|c|c|c|}
\hline \multicolumn{9}{|c|}{ Panel A: Initiate $_{t}$} \\
\hline $\mathrm{VW} P_{t-1}^{D-N D}$ & $\begin{array}{c}2.80 \\
{[0.34]}\end{array}$ & & & & & & & $\begin{array}{l}-0.98 \\
{[0.78]}\end{array}$ \\
\hline VW Nonpayer $M / B_{t-1}$ & & $\begin{array}{c}1.29 \\
{[0.66]}\end{array}$ & & & & & & $\begin{array}{l}-3.37 \\
{[0.56]}\end{array}$ \\
\hline $\mathrm{VW} D / P_{t-1}$ & & & $\begin{array}{c}-7.86 * * \\
{[0.00]}\end{array}$ & & & $\begin{array}{c}-8.18 * * \\
{[0.00]}\end{array}$ & $\begin{array}{c}-8.66^{* *} \\
{[0.00]}\end{array}$ & $\begin{array}{c}-10.49^{*} \\
{[0.02]}\end{array}$ \\
\hline $\operatorname{Tax}_{t-1}$ & & & & $\begin{array}{l}5.83^{*} \\
{[0.05]}\end{array}$ & & $\begin{array}{l}6.32^{*} \\
{[0.05]}\end{array}$ & $\begin{array}{c}8.24 \\
{[0.12]}\end{array}$ & $\begin{array}{c}9.93 \\
{[0.27]}\end{array}$ \\
\hline Year $_{t-1}$ & & & & & $\begin{array}{c}0.81 \\
{[0.21]}\end{array}$ & & $\begin{array}{l}-0.41 \\
{[0.62]}\end{array}$ & $\begin{array}{l}-0.90 \\
{[0.63]}\end{array}$ \\
\hline $\begin{array}{l}N \\
\text { Adj.R }\end{array}$ & $\begin{array}{c}20 \\
-0.02\end{array}$ & $\begin{array}{c}20 \\
-0.05\end{array}$ & $\begin{array}{c}20 \\
0.30\end{array}$ & $\begin{array}{c}20 \\
0.09\end{array}$ & $\begin{array}{l}20 \\
0.06\end{array}$ & $\begin{array}{c}20 \\
0.40\end{array}$ & $\begin{array}{c}20 \\
0.38\end{array}$ & $\begin{array}{l}20 \\
0.30\end{array}$ \\
\hline \multicolumn{9}{|c|}{ Panel B: Continue $_{t}$} \\
\hline $\mathrm{V} \mathrm{WP} P_{t-1}^{D-N D}$ & $\begin{array}{l}-1.13 \\
{[0.24]}\end{array}$ & & & & & & & \\
\hline VW Payer $M / B_{t-1}$ & & $\begin{array}{c}0.80 \\
{[0.38]}\end{array}$ & & & & & & \\
\hline $\mathrm{VW} D / P_{t-1}$ & & & $\begin{array}{l}-1.17 \\
{[0.20]}\end{array}$ & & & & & \\
\hline $\operatorname{Tax}_{t-1}$ & & & & $\begin{array}{c}0.43 \\
{[0.64]}\end{array}$ & & & & \\
\hline Year $_{t-1}$ & & & & & $\begin{array}{l}-0.16 \\
{[0.36]}\end{array}$ & & & \\
\hline$N$ & 20 & 20 & 20 & 20 & 20 & & & \\
\hline $\operatorname{Adj} . R^{2}$ & 0.02 & -0.02 & 0.03 & -0.05 & 0.00 & & & \\
\hline
\end{tabular}

Notes: Regressions of dividend payment rates on measures of the dividend premium, growth opportunities, dividend yield, the personal tax advantage of dividends versus capital gains, and a time trend are performed. For example, the initiation rate is modeled in Panel A as:

Initiate $_{t}=\alpha+\theta_{1} V W P^{D-N D}{ }_{t-1}+\theta_{2}$ VWNonpayer $M / B_{t-1}+\theta_{3} V W D / P_{t-1}+\theta_{4}$ Tax $_{t-1}+\theta_{5}$ Year $_{t-1}+\tau_{t}$.

The initiation rate Initiate expresses payers as a percentage of surviving nonpayers from $t-1$. The continuation rate Continue expresses payers as a percentage of surviving payers from $t-1$. The dividend premium $P^{D-N D}$ is the difference between the logs of the book value-weighted market-to-book ratios for dividend payers and nonpayers. Tax is the ratio of after-tax income from a yen in dividends to after-tax income from a yen in long-term capital gains. Year is the calendar year. All independent variables but Year are standardized to unit variance. $p$-values are derived by using the method of Newey and West (1987), hence they are robust to heteroskedasticity and serial correlation. $N$ is the number of sample and $A d j . R^{2}$ is the adjusted $R$-squared value. $*$ denotes statistical significance at the $5 \%$ level and $* *$ denotes statistical significance at the $1 \%$ level.

\section{Summary and Conclusions}

This paper tested catering theory of dividends in the Japanese electrical appliances industry. We found the following new interesting evidence.

(1) Our results revealed that the dividend initiation decisions of Japanese electrical appliances industry firms have no predictive power for relative future negative returns of payers over nonpayers. This evidence is inconsistent with the suggestions of catering theory of dividends by BW (2004a). More precisely, the excess returns of payers over nonpayers is statistically significantly negative in the US, while future excess returns of payers over nonpayers are positive in the Japanese electrical appliances industry firms. 
Table 7. Dividend Payment and the Dividend Premium: Tests with Market Value-Weighted Other Variables

\begin{tabular}{|c|c|c|c|c|c|c|c|c|}
\hline \multicolumn{9}{|c|}{ Panel A: Initiate ${ }_{t}$} \\
\hline $\operatorname{MVWP}_{t-1}^{D-N D}$ & $\begin{array}{c}2.78 \\
{[0.30]}\end{array}$ & & & & & & & $\begin{array}{l}-1.72 \\
{[0.57]}\end{array}$ \\
\hline MVW Nonpayer $M / B_{t-1}$ & & $\begin{array}{c}2.10 \\
{[0.38]}\end{array}$ & & & & & & $\begin{array}{l}-2.77 \\
{[0.59]}\end{array}$ \\
\hline MVW $D / P_{t-1}$ & & & $\begin{array}{l}-6.60^{* *} \\
{[0.01]}\end{array}$ & & & $\begin{array}{c}-7.50 * * \\
{[0.00]}\end{array}$ & $\begin{array}{c}-8.61 * * \\
{[0.00]}\end{array}$ & $\begin{array}{c}-10.63^{*} \\
{[0.03]}\end{array}$ \\
\hline $\operatorname{Tax}_{t-1}$ & & & & $\begin{array}{l}5.83^{*} \\
{[0.05]}\end{array}$ & & $\begin{array}{l}6.97^{*} \\
{[0.03]}\end{array}$ & $\begin{array}{l}10.19 \\
{[0.06]}\end{array}$ & $\begin{array}{l}11.54 \\
{[0.22]}\end{array}$ \\
\hline Year $_{t-1}$ & & & & & $\begin{array}{c}0.81 \\
{[0.21]}\end{array}$ & & $\begin{array}{l}-0.66 \\
{[0.45]}\end{array}$ & $\begin{array}{l}-0.95 \\
{[0.58]}\end{array}$ \\
\hline $\begin{array}{l}N \\
\text { Adj. } R^{2}\end{array}$ & $\begin{array}{c}20 \\
-0.02 \\
\end{array}$ & $\begin{array}{c}20 \\
-0.03 \\
\end{array}$ & $\begin{array}{c}20 \\
0.17 \\
\end{array}$ & $\begin{array}{c}20 \\
0.09 \\
\end{array}$ & $\begin{array}{c}20 \\
0.06 \\
\end{array}$ & $\begin{array}{c}20 \\
0.34 \\
\end{array}$ & $\begin{array}{c}20 \\
0.33\end{array}$ & $\begin{array}{l}20 \\
0.24\end{array}$ \\
\hline \multicolumn{9}{|c|}{ Panel B: Continue $_{t}$} \\
\hline $\operatorname{MVW} P^{D-N D}{ }_{t-1}$ & $\begin{array}{l}-1.05 \\
{[0.25]}\end{array}$ & & & & & & & \\
\hline MVW Payer $M / B_{t-1}$ & & $\begin{array}{c}0.14 \\
{[0.82]}\end{array}$ & & & & & & \\
\hline MVW $D / P_{t-1}$ & & & $\begin{array}{l}-0.60 \\
{[0.60]}\end{array}$ & & & & & \\
\hline $\operatorname{Tax}_{t-1}$ & & & & $\begin{array}{c}0.43 \\
{[0.64]}\end{array}$ & & & & \\
\hline Year $_{t-1}$ & & & & & $\begin{array}{l}-0.16 \\
{[0.36]}\end{array}$ & & & \\
\hline $\begin{array}{l}N \\
\text { Adj. } R^{2}\end{array}$ & $\begin{array}{c}20 \\
0.01\end{array}$ & $\begin{array}{c}20 \\
-0.05\end{array}$ & $\begin{array}{c}20 \\
-0.03\end{array}$ & $\begin{array}{c}20 \\
-0.05\end{array}$ & $\begin{array}{c}20 \\
0.00\end{array}$ & & & \\
\hline
\end{tabular}

Notes: Regressions of dividend payment rates on measures of the dividend premium, growth opportunities, dividend yield, the personal tax advantage of dividends versus capital gains, and a time trend are performed. For example, the initiation rate is modeled in Panel A as:

Initiate $_{t}=\alpha+\theta_{1} M V W P^{D-N D}{ }_{t-1}+\theta_{2}$ MVWNonpayer $M / B_{t-1}+\theta_{3} M V W D / P_{t-1}+\theta_{4}$ Tax $_{t-1}+\theta_{5}$ Year $_{t-1}+\tau_{t}$.

The initiation rate Initiate expresses payers as a percentage of surviving nonpayers from $t-1$. The continuation rate Continue expresses payers as a percentage of surviving payers from $t-1$. The dividend premium $P^{D-N D}$ is the difference between the logs of the market value-weighted market-to-book ratios for dividend payers and nonpayers. Tax is the ratio of after-tax income from a yen in dividends to after-tax income from a yen in long-term capital gains. Year is the calendar year. All independent variables but Year are standardized to unit variance. $t$-statistics use standard errors obtained by using the method of Newey and West (1987), hence they are robust to heteroskedasticity and serial correlation. $N$ is the number of sample and $A d j . R^{2}$ is the adjusted $R$-squared value. * denotes statistical significance at the $5 \%$ level and ** denotes statistical significance at the $1 \%$ level.

(2) Most importantly, with regard to the dividend initiations and continuations of the Japanese electrical appliances industry firms, the dividend premium is not a determinant. This means that the electrical appliances industry firms in Japan do not behave according to the prediction of catering theory.

(3) Instead, in contrast to the US case, regarding dividend initiations, the value-weighted dividend yield is a strong determinant of one-year-ahead dividend initiations in the Japanese electrical appliances industry firms. This can be interpreted such as a type of market timing behavior related to dividend initiation by the industry's corporations.

As indicated above, the new evidence presented in this paper contributes to important issues in dividend policy in corporate finance. Future academic studies with large datasets of Japanese firms using additional information would be valuable. These studies may produce stronger and more comprehensive conclusions, and this is our future objective. 


\section{Acknowledgement}

We thank the Japan Society for the Promotion of Science, the Zengin Foundation for Studies on Economics and Finance, and Nihon Housei Gakkai for their generous financial assistance for this research. Finally, we greatly appreciate the invitation of Lucy Xu (the Editor) to write for this journal.

\section{References}

Allen, F., Bernardo, A. E., \& Welch, I. (2000). A theory of dividends based on tax clienteles. Journal of Finance, 55, 2499-2536.

Allen, F., \& Michaely, R. (2002). Payout policy, Working paper, University of Pennsylvania.

Asquith, P., \& Mullins, D. W. (1983). The impact of initiating dividend payments on shareholders' wealth. Journal of Business, 56, 77-96.

Bagwell, L. S., \& Shoven, J. B. (1989). Cash distributions to shareholders. Journal of Economic Perspectives, 3, 129-140.

Baker, H., Farrelly, K. G. E., \& Edelman, R. B. (1985). A survey of management views on dividend policy. Financial Management, 14, 78-84.

Baker, M., \& Wurgler, J. A. (2004a). Catering Theory of Dividends. Journal of Finance, 59, 1125-1165.

Baker, M., \& Wurgler, J. A. (2004b). Appearing and Disappearing Dividends: The Link to Catering Incentives. Journal of Financial Economics, 73, 271-288.

Benartzi, S., Michaely, R., \& Thaler, R. (1997). Do changes in dividends signal the future or the past? Journal of Finance, 52, 1007-1034.

Bhattacharya, S. (1979). Imperfect information, dividend policy, and 'the bird in the hand fallacy', Bell Journal of Economics, 10, 259-270.

Black, F. (1976). The dividend puzzle. Journal of Portfolio Management, 2, 5-8.

Black, F., \& Scholes, M. (1974). The effects of dividend yield and dividend policy on common stock prices and returns. Journal of Financial Economics, 1, 1-22.

Brav, A., Graham, J. R., Harvey, C., \& Michaely, R. (2003). Payout policy in the 21 st century, Working paper, Duke University.

Brav, A., \& Heaton, J. B. (1998). Did ERISA's prudent man rule change the pricing of dividend omitting firms? Working paper, Duke University.

Dann, L. Y. (1981). Common stock repurchases: An analysis of returns to bondholders and stockholders. Journal of Financial Economics, 9, 113-138.

DeAngelo, H., DeAngelo, L., \& Skinner, D. J. (1996). Dividend signaling and the disappearance of sustained earnings growth. Journal of Finance, 40, 341-371. 


\section{Macrothink}

Journal of Management Research

ISSN 1941-899X

2010, Vol. 2, No. 2: E6

Eades, K. M., Hess, P. J., \& Kim, E. H. (1994). Time-series variation in dividend pricing. Journal of Finance, 49, 1617-1638.

Fama, E. F., \& Babiak, H. (1968). Dividend policy: An empirical analysis. Journal of the American Statistical Association, 53, 1132-1161.

Fama, E. F., \& French, K. R. (1993). Common risk factors in the returns on stocks and bonds. Journal of Financial Economics, 33, 3-56.

Fama, E. F., \& French, K. R. (1996). Multifactor explanations of asset pricing anomalies. Journal of Finance, 51, 55-84.

Fama, E. F., \& French, K. R. (2001). Disappearing dividends: Changing firm characteristics or lower propensity to pay? Journal of Financial Economics, 60, 3-44.

Feenberg, D., \& Coutts, E. (1993). An introduction to the Taxsim model. Journal of Policy Analysis and Management, 12, 189-194.

Graham, J. R., \& Harvey, C. R. (2001). The theory and practice of corporate finance: Evidence from the field. Journal of Financial Economics, 60, 187-244.

Graham, J. R., \& Kumar, A. (2003). Do dividend clienteles exist? Evidence on dividend preferences of retail investors. Working paper, Duke University.

Hakansson, N. H. (1982). To pay or not to pay dividends. Journal of Finance, 37, 415-428.

Healy, P. M., \& Palepu, K. G. (1988). Earnings information conveyed by dividend initiations and omissions. Journal of Financial Economics, 21, 149-176.

Hubbard, J., \& Michaely, R. (1997). Do investors ignore dividend taxation? A reexamination of the Citizens Utilities case. Journal of Financial and Quantitative Analysis, 32, 117-135.

John, K., \& Williams, J. (1985). Dividends, dilution, and taxes: A signaling equilibrium. Journal of Finance, 40, 1053-1070.

Kothari, S. P., \& Shanken, J. (1997). Book-to-market, dividend yield, and expected market returns: A time series analysis. Journal of Financial Economics, 44, 169-203.

La Porta, R., Lopez-de-Silanes, F., Shleifer, A., \& Vishny, R. (2000). Agency problems and dividend policies around the world. Journal of Finance, 55, 1-33.

Lintner, J. (1956). The distribution of incomes of corporations among dividends, retained earnings, and taxes. American Economic Review, 46, 97-113.

Liu, Y., Szewczyk, S., \& Zantout, Z. (2003). An examination of the long-run market reaction to announcement of dividend omissions and reductions. Working paper, Drexel University.

Long, J. B. (1978). The market valuation of cash dividends: A case to consider. Journal of Financial Economics, 6, 235-264.

Marsh, T. A., \& Merton, R. C. (1987). Dividend behavior for the aggregate stock market. Journal of Business, 60, 1-40. 
Michaely, R., Thaler, R. H., \& Womack, K. L. (1995). Price reactions to dividend initiations and omissions: Overreaction or drift? Journal of Finance, 50, 573-608.

Miller, M. H. (1977). Debt and taxes. Journal of Finance, 32, 261-275.

Miller, M. H., \& Modigliani, F. (1961). Dividend policy, growth and the valuation of shares. Journal of Business, 34, 411-433.

Miller, M. H., \& Rock, K. (1985). Dividend policy under asymmetric information. Journal of Finance, 40, 1031-1051.

Miller, M. H., \& Scholes, M. (1978). Dividends and taxes. Journal of Financial Economics, 6, 333-364.

Newey, W. K., \& West, K. D. (1987). A simple, positive semi-definite, heteroskedasticity and autocorrelation consistent covariance matrix. Econometrica, 55, 703-708.

Peterson, P., Peterson, D., \& Ang, J. (1985). Direct evidence on the marginal rate of taxation on dividend income. Journal of Financial Economics, 14, 267-282.

Poterba, J. M. (1986). The market valuation of cash dividends: The Citizens Utilities case reconsidered. Journal of Financial Economics, 15, 395-405.

Shefrin, H. M., \& Statman, M. (1984). Explaining investor preference for cash dividends. Journal of Financial Economics, 13, 253-282.

Shleifer, A. (2000). Inefficient markets: An introduction to behavioral finance. Oxford University Press, Oxford, UK.

Stein, J. C. (1989). Efficient capital markets, inefficient firms: A model of myopic corporate behavior. Quarterly Journal of Economics, 104, 655-669.

Stein, J. C. (1996). Rational capital budgeting in an irrational world. Journal of Business, 69, 429-455.

Watts, R. (1973). The information content of dividends. Journal of Business, 46, 191-211.

\section{Notes}

Note 1. Important studies which follow MM (1961) are those as Allen et al. (2000), Allen and Michaely (2002), Asquith and Mullins (1983), Bagwell and Shoven (1989), Baker et al. (1985), Baker and Wurgler (2004a, 2004b), Benartzi et al. (1997), Bhattacharya (1979), Black (1976), Black and Scholes (1974), Brav et al. (2003), Brav and Heaton (1998), Dann (1981), DeAngelo et al. (1996), Eades et al. (1994), Fama and Babiak (1968), Fama and French (2001), Feenberg and Coutts (1993), Graham and Harvey (2001), Graham and Kumar (2003), Hakansson (1982), Healy and Palepu (1988), Hubbard and Michaely (1997), John and Williams (1985), Kothari and Shanken (1997), La Porta et al. (2000), Lintner (1956), Liu et al. (2003), Long (1978), Marsh and Merton (1987), Michaely et al. (1995), Miller (1977), Miller and Rock (1985), Miller and Scholes (1978), Peterson et al. (1985), Poterba (1986), Shefrin and Statman (1984), and Watts (1973), for example. 
Note 2. Inefficient markets are recently advocated by such studies as Shleifer (2000) and Stein $(1989,1996)$. 